\title{
PENERAPAN LAYANAN BIMBINGAN KELOMPOK UNTUK MENINGKATKAN PERENCANAAN STUDI LANJUT PADA SISWA
}

\section{THE APPLICATION OF GROUP GUIDANCE SERVICES FOR IMPROVING STUDY PLANNING ON STUDENTS}

\author{
Nur Khixmah Yulihastuti \\ SMA Negeri 2 Pati \\ Jl. A. Yani No. 4 Pati. 59112. Jawa Tengah
}

Naskah Masuk: 9 Agustus 2019 Naskah Revisi: 21 September 2019 Naskah Diterima: 30 Oktober 2019

\begin{abstract}
This Classroom Action Research is triggered by the existence of students from Public High School 2 in Pati who did not continue their education to higher education due to social problems that became obstacles for them in planning further studies. The purpose of this study was to improve further study planning in class XII IPA, Public High School 2 in Pati in the Academic Year conducted in two cycles, each cycle consisting of two meetings. In each cycle includes several stages: the formation stage, the transitional stage, the activity stage and the termination stage. The results of the study showed that there was an increase for students in their advanced study planning. This can be found that in the initial conditions of students experiencing social problems are 10 children, it became 5 children in cycle 1 and in cycle 2 as many as 0 children. The percentage increase in advanced study planning from $74.36 \%$ to $100 \%$. The conclusion that the effectiveness of group guidance services with successful educational alumni modeling approach is able to improve advanced study planning.
\end{abstract}

Keywords: group guidance services, modeling success, advanced studies

\section{ABSTRAK}

Beberapa siswa SMA Negeri 2 Pati mengalami problem sosial sehingga menghalangi mereka dalam perencanaan studi lanjut ke perguruan tinggi. Tujuan penelitian ini adalah untuk meningkatkan perencanaan studi lanjut pada kelas XII IPA 3 SMA Negeri 2 Pati tahun ajaran 2019/2020. Penelitian dilakukan dalam dua siklus, setiap siklus terdiri dari 2 pertemuan. Tiap siklus meliputi beberapa tahap, antara lain: tahap pembentukan, peralihan, kegiatan, dan tahap pengakhiran. Hasil penelitian menunjukkan peningkatan siswa dalam perencanaan studi lanjut. Hal ini dapat dilihat pada kondisi awal siswa yang mengalami problem sosial sebanyak 10 siswa, pada siklus 1 sebanyak 5 siswa dan pada siklus 2 sebanyak 0 siswa. Persentase peningkatan perencanaan studi lanjut dari 74,36\% hingga 100\%. Kesimpulannya bahwa efektivitas layanan bimbingan kelompok dengan pendekatan modeling alumni sukses pendidikan mampu meningkatkan perencanaan studi lanjut.

Kata kunci: layanan bimbingan kelompok, modelling sukses, studi lanjut

\section{PENDAHULUAN}

Perencanaan studi lanjut merupakan hal yang perlu diperhatikan pada siswa kelas XII dalam penentuan masa depan siswa. Beberapa siswa alumni Sekolah Menengah Atas (SMA) Negeri 2 Pati tidak meneruskan pendidikannya ke perguruan tinggi disebabkan kurangnya modal pada diri siswa untuk menghadapi masalah terutama problem sosial. Berdasarkan observasi awal pada siswa XII IPA 3 dengan menggunakan daftar pertanyaan diperoleh data siswa yang mengalami problem sosial sebanyak 10 siswa.
Usia SMA merupakan masa usia remaja akhir yang memiliki ciri sikap antara lain: perasaan dan emosi yang tidak stabil atau mengalami kegelisahan, mengalami pertentangan dalam dirinya, mengkhayal, keinginan mencoba sesuatu, aktivitas yang selalu berkelompok, jati diri remaja masih sulit ditemukan, kemampuan mental dan daya pikir mulai agak sempurna, sikap dan moral menonjol (Syamsudin, 2012). Karakteristik tersebut berpotensi memunculkan permasalahan pada siswa terutama dalam hal pengambilan keputusan. Siswa masih cenderung mudah terbawa oleh iming-iming yang sepertinya 
menarik, namun belum tentu merupakan pilihan yang tepat dengan kondisi siswa. Permasalahan pengambilan keputusan siswa tersebut berpengaruh terhadap proses perencanaan masa depan, salah satunya dalam hal pengambilan keputusan mengenai studi lanjut.

Banyak faktor yang menjadi penyebab siswa memutuskan untuk tidak melanjutkan dan atau melanjutkan studi, yaitu faktor eksternal dan internal. Faktor eksternal yaitu kurangnya biaya ekonomi keluarga, kurangnya motivasi dan dukungan dari orang tua, tidak terpenuhinya persyaratan dan hambatan waktu, tingginya biaya untuk melakukan studi lanjut, serta pengaruh lingkungan masyarakat sekitar. Faktor internalnya yaitu kurangnya minat belajar siswa terhadap dunia pendidikan dalam studi lanjut, kurangnya harapan dari diri sendiri untuk menjadi lebih maju, dan untuk memperoleh pekerjaan yang lebih baik (Nafisah, 2016). Hasil observasi di SMA N 2 Pati menunjukkan bahwa permasalahan yang sangat berpengaruh dalam proses menentukan studi lanjut, diantaranya adalah keputusan meninggalkan sekolah, motivasi belajar, pengambilan keputusan ke perguruan tinggi, dan problem sosial siswa.

Siswa yang telah lulus dari sekolah menengah atas dihadapkan pada pilihan-pilihan sulit. Seorang siswa dalam kehidupannya akan dihadapkan dengan sejumlah alternatif, baik yang berhubungan dengan kehidupan pribadi, sosial, belajar maupun karirnya. Adakalanya siswa mengalami kesulitan untuk mengambil keputusan dalam menentukan alternatif mana yang sebaiknya dipilih. Apakah nantinya akan meneruskan studi lanjut yakni melanjutkan pendidikan ke perguruan tinggi, atau akan bekerja maupun mengikuti pelatihan untuk menambah ketrampilan.

Siswa harus memiliki informasi mengenai studi lanjut yang memadai dan sesuai agar dapat mengambil keputusan mengenai studi lanjut. Hal ini menjadi dasar bagi guru pembimbing untuk melaksanakan bimbingan mengenai studi lanjut. Guru pembimbing memilih layanan bimbingan kelompok dengan pendekatan modeling alumni sukses pendidikan karena dirasa mampu mengantisipasi permasalahan yang dihadapi siswa dan dapat memotivasi siswa untuk mengambil keputusan studi lanjut yang tepat. Penelitian ini bertujuan untuk meningkatkan perencanaan studi lanjut agar siswa lebih tertata dalam pemilihan studi lanjutnya.

\section{TINJAUAN PUSTAKA}

\section{Perencanaan Studi Lanjut}

Ward \& Peppard (2012) menyatakan bahwa perencanaan merupakan sebuah analisis yang menyeluruh dan sistematis dalam mengembangkan sebuah rencana kegiatan. Perencanaan adalah proses untuk mengkaji apa yang hendak dikerjakan di masa datang secara menyeluruh dengan harapan memiliki keberhasilan sesuai rencana.

Pengertian studi lanjut menurut Setyowati \& Nursalim (2009) adalah pendidikan lanjutan atau sambungan setelah tamat dari Sekolah Menengah Atas (SMA) atau pendidikan yang lebih tinggi. Studi lanjut adalah usaha untuk menelaah hasil layanan kepada siswa yang telah meninggalkan sekolah itu, baik karena droup out, melanjutkan studi, atau bekerja (Iwanramadanie, 2019).

\section{Layanan Bimbingan Kelompok}

Layanan bimbingan kelompok dimaksudkan untuk memungkinkan siswa secara bersama-sama memperoleh berbagai bahan dari narasumber yang bermanfaat untuk kehidupan sehari-hari, baik sebagai individu maupun sebagai pelajar, anggota keluarga dan masyarakat. Bahan yang dimaksudkan dapat juga dipergunakan sebagai acuan untuk mengambil keputusan. Lebih jauh dengan layanan bimbingan kelompok, para siswa dapat diajak untuk bersama-sama mengemukakan pendapat tentang sesuatu dan membicarakan topik-topik penting, mengembangkan nilai-nilai yang berhubungan dengan hal tersebut dan mengembangkan langkah-langkah bersama untuk menangani permasalahan yang dibahas di dalam kelompok (Luddin, 2010). Layanan bimbingan kelompok merupakan cara 
memberikan bantuan (bimbingan) kepada siswa melalui kegiatan kelompok (Tohirin, 2011).

\section{Bimbingan Kelompok Teknik Modeling Alumni Sukses Pendidikan}

Teknik modeling melibatkan prosesproses kognitif, tidak hanya meniru, lebih dari sekedar menyesuaikan diri dengan tindakan orang lain karena sudah melibatkan keterwakilan informasi secara simbolis dan menyimpannya untuk digunakan di masa depan (Alwisol, 2009). Teknik modeling bukan sekedar menirukan atau mengulangi apa yang dilakukan oleh model (orang lain), tetapi modeling melibatkan penambahan dan atau pengurangan tingkah laku yang teramati, menggenalisir berbagai pengamatan sekaligus, melibatkan proses kognitif (Yulihastuti, 2018).

Definisi pendidikan menurut UU No. 20 Tahun 2003 tentang Sistem Pendidikan Nasional, Pasal 1 Butir 1 (sebagaimana telah dikutip pada bab XI) mengandung penegasan tentang pendidikan yaitu apa yang dicapai atau yang dimiliki peserta didik adalah sesuatu yang berguna bagi dirinya, masyarakat, bangsa dan negara.

Alumni sukses pendidikan adalah orangorang yang telah mengikuti atau tamat dari suatu sekolah atau perguruan tinggi yang sukses. Sukses adalah jika kita bisa mendapatkan apa yang kita inginkan tanpa merugikan orang lain dan kita bisa menerimanya dengan senang hati, kemudian kita bisa membantu banyak orang yang membutuhkan uluran tangan kita dengan belas kasih dan tulus ikhlas dengan penuh rasa puas (Wuryanano, 2009). Menurut Khera dalam Munadi (2010) sukses adalah keberhasilan dalam mencapai target yang telah ditentukan mencakup apa pun dan sebesar apa pun.

Masraroh \& Latifatul (2012) menyatakan bahwa bimbingan kelompok dengan teknik modeling diharapkan mampu mengembangkan performa self efficacy pada siswa. Sebagaimana dalam paparan di atas bahwa guru dan teman sebaya memberikan peran yang penting dalam meningkatkan self efficacy siswa. Harpine dalam
Masraroh \& Latifatul (2012) mengembangkan program bimbingan yang berpusat pada kelompok dalam Camp Sharigan (sebuah program motivasi) bersama siswa dan remaja mampu mengembangkan self efficacy siswa dan remaja dengan baik.

\section{Tahapan dalam Bimbingan Kelompok}

\section{Tahap I: Pembentukan}

Tema: Pengenalan, pelibatan diri, dan pemasukan diri.

Tujuan:

1. Anggota memahami pengamatan dan kegiatan kelompok dalam rangka bimbingan kelompok.

2. Menumbuhkan suasana kelompok.

3. menumbuhkan minat anggota mengikuti kegiatan kelompok.

4. Menumbuhkan sikap saling mengenal, percaya, menerima, dan membantu di antara para anggota.

5. Menumbuhkan suasana bebas terbuka.

6. Membahas tentang tingkah laku dan perasaan dalam kelompok.

\section{Kegiatan:}

1. Mengungkapkan pengertian dan tujuan kegiatan kelompok dalam rangka pelayanan bimbingan kelompok.

2. Menjelaskan cara-cara dan asas-asas kegiatan kelompok.

3. Saling memperkenalkan dan mengungkapkan diri.

4. Teknik khusus.

5. Permainan, penghangatan, pengakraban.

Peranan guru pembimbing:

1. Menampilkan diri secara utuh dan terbuka.

2. Menampilkan penghormatan kepada anggota kelompok, hangat, tulus, bersedia membantu, dan penuh empati.

\section{Tahap II: Peralihan}

Tema: Pembangunan jembatan antara tahap pertama dan tahap ketiga.

Tujuan:

1. Membebaskan anggota dari perasaan atau sikap enggan, ragu, malu, atau saling tidak percaya untuk memasuki tahap berikutnya. 
2. Memantapkan suasana kelompok dan kebersamaan.

3. Memantapkan minat untuk ikut serta dalam kegiatan kelompok.

Kegiatan:

1. Menjelaskan kegiatan yang akan ditempuh pada tahap berikutnya.

2. Menawarkan atau mengamati apakah para anggota sudah siap menjalani kegiatan pada tahap selanjutnya (tahap kegiatan).

3. Membahas suasana yang terjadi.

4. Meningkatkan kemampuan keikutsertaan anggota.

5. Kalau perlu ke beberapa aspek tahap pertama (tahap pembentukan).

Peranan guru pembimbing:

1. Pengatur lalu lintas yang sabar dan terbuka.

2. Aktif tetapi tidak banyak bicara.

Tahap III: Kegiatan (Kelompok Tugas)

Tema: Kegiatan pencapaian tujuan

(Pembahasan Tugas)

Tujuan:

1. Membahas suatu masalah atau topik yang relevan dengan kehidupan anggota secara mendalam dan tuntas.

2. Melibatkan seluruh anggota secara aktif dan dinamis dalam pembahasan baik yang menyangkut unsur-unsur tingkah laku, pemikiran ataupun perasaan.

Kegiatan:

1. Membagi siswa dalam beberapa kelompok.

2. Memasukkan 1 orang alumni sukses pendidikan ke dalam setiap kelompok.

3. Melaksanakan kegiatan diskusi dalam kelompok dan pengenalan pengalaman alumni sukses pendidikan kepada siswa untuk memberikan motivasi untuk meningkatkan perencanaan studi lanjut.

Peranan guru pembimbing sebagai pengamat dalam setiap kegiatan.

\section{Tahap IV: Pengakhiran}

Tema: Penilaian dan tindak lanjut.

Tujuan:

1. Mengungkapkan kesan-kesan anggota kelompok tentang pelaksanaan kegiatan.
2. Mengungkapkan hasil kegiatan kelompok yang telah dicapai yang dikemukakan secara mendalam dan tuntas.

3. Merumuskan rencana kegiatan lebih lanjut.

4. Mempertahankan hubungan kelompok dan kebersamaan meskipun kegiatan diakhiri.

Kegiatan:

1. Guru Bimbingan dan Konseling membuat kesimpulan atas penelitian.

2. Guru BK merumuskan kegiatan selanjutnya dengan melihat kekurangan yang masih ada.

3. Guru BK memberikan kegiatan yang dapat mempertahankan kebersamaan antar kelompok.

Peranan guru pembimbing:

1. Melakukan refleksi.

2. Menyusun kegiatan selanjutnya.

3. Membuat kesimpulan.

\section{METODE PENELITIAN}

Penelitian Tindakan Bimbingan Konseling (PTBK) ini dilakukan selama 4 bulan, yaitu bulan Januari sampai bulan April 2019. Subjek penelitian adalah siswa kelas XII IPA3 SMA Negeri 2 Pati semester genap tahun 2018/2019, sebanyak 39 siswa. Sampel dipilih kelas XII IPA 3 karena para siswa memiliki pilihan yang bervariasi mengenai rencana yang akan dilakukan setelah lulus SMA diantaranya memilih untuk bekerja, melanjutkan ke perguruan tinggi, masih memiliki problem sosial dalam memilih perguruan tinggi, dan mengikuti kursus setelah lulus.

Pengumpulan data dalam PTBK, menggunakan teknik observasi, yang ditujukan pada 3 sasaran yaitu: 1) Guru Bimbingan Konseling. Fokus pengamatan pada tindakan konkret guru pembimbing dalam mengatasi problem sosial siswa, yaitu menggunakan layanan bimbingan kelompok dengan menggunakan modeling alumni sukses pendidikan; 2) siswa. Fokus pengamatan pada saat siswa mengikuti layanan bimbingan kelompok dan mengisi daftar pertanyaan tentang rencana setelah lulus yang diberikan oleh guru pembimbing; 3) situasi dan kondisi 
saat berlangsungnya layanan bimbingan kelompok.

Penelitian dengan menggunakan observasi adalah teknik evaluasi dengan cara mengadakan pengamatan secara teliti dan pencatatan secara sistematis terhadap fenomena yang sedang dijadikan sasaran pengamatan. Teknik observasi memiliki beberapa keunggulan, yaitu; 1) data observasi diperoleh secara langsung di lapangan ; 2) data observasi dapat mencakup berbagai aspek kepribadian masing-masing siswa. Alat yang digunakan dalam pengumpulan data observasi adalah pedoman observasi yang dibuat oleh guru pembimbing peneliti dan kolaborator penelitian.

Hipotesis tindakan dalam penelitian ini adalah melalui layanan bimbingan kelompok dapat meningkatkan perencanaan studi lanjut menggunakan modeling alumni sukses pendidikan bagi siswa kelas XII IPA3 SMA Negeri 2 Pati semester genap tahun 2018/2019. Analisis data dengan diskriptif komparatif karena membandingkan peningkatan perencanaan studi lanjut antara kondisi awal dengan siklus 1 , dan membandingkan peningkatan perencanaan studi lanjut antara siklus 1 dan siklus 2 .

Perencanaan studi lanjut pada kondisi awal didapat dari keadaan siswa sebelum dilakukan penelitian, yang diperoleh dari hasil kuesioner tentang rencana studi lanjut setelah kelulusan. Siklus 1, bimbingan kelompok membahas rencana studi lanjut dengan memasukkan modeling alumni sukses pendidikan. Siklus 2, data proses diperoleh seperti pada siklus 1 dengan perubahan berdasarkan hasil refleksi siklus 1, dan perencanaan studi lanjut siswa diperoleh dari persentase dari indikator yang sudah ditetapkan, kemudian dibandingkan dengan kondisi awal dan siklus 1. Materi yang disampaikan pada siklus 2 membahas tentang hambatan-hambatan yang dialami oleh siswa, sehingga perencanaan studi lanjut siswa menjadi lebih terarah dan sesuai dengan keadaan siswa.
Indikator keberhasilan dalam penelitian ini adalah siswa dapat meningkatkan perencanaan studi lanjut setelah mendapatkan layanan bimbingan kelompok dengan menggunakan modeling alumni sukses pendidikan. Kriteria peningkatan antara siklus I dan siklus II yaitu apabila sekurang-kurangnya $75 \%$ siswa SMA Negeri 2 Pati anggota bimbingan kelompok sudah dapat merencanakan studi lanjut dengan tepat.

Proses peningkatan perencanaan studi lanjut yang diberikan oleh guru pembimbing melalui bimbingan kelompok dengan modeling alumni sukses pendidikan, menekankan pada 2 aspek yaitu: aspek pemahaman dan perencanaan. Aspek pemahaman, siswa diharapkan mampu mengidentifikasi problem yang dihadapi sehingga perencanaan studi lanjutnya lebih relevan dengan keadaan. Hal ini diamati melalui keterlibatan siswa dalam mengikuti layanan bimbingan kelompok. Aspek perencanaan, siswa diharapkan sudah mampu merencanakan studi lanjut berdasarkan informasi dari modeling alumni sukses pendidikan. Hal ini dilihat berdasarkan hasil pengisian kuesioner tentang rencana setelah lulus SMA.

Penelitian dilaksanakan dalam 2 tahap (2 siklus). Tiap siklus dilaksanakan 2 kali kegiatan, sesuai dengan indikator perubahan tingkah laku yang hendak dicapai. Hasil tiap siklus digunakan untuk merefleksikan langkah yang harus dilakukan berikutnya. Masing-masing siklus terdiri dari: perencanaan (planning), pelaksanaan tindakan (action), pengamatan (observation, refleksi (reflection).

Urutan langkah penelitian tindakan bimbingan konseling dapat digambarkan sebagai berikut:

Siklus I

1) Perencanaan (Planning)

Kegiatan yang dilakukan pada tahap perencanaan meliputi:

a) Membuat skenario layanan bimbingan dengan menggunakan metode bimbingan kelompok. 
b) Membuat pedoman observasi untuk melihat aktivitas guru pembimbing dalam melaksanakan bimbingan kelompok.

c) Membuat pedoman observasi untuk siswa sewaktu mengikuti kegiatan bimbingan kelompok.

d) Membuat pedoman observasi untuk mengamati situasi dan kondisi pada saat kegiatan layanan bimbingan kelompok berlangsung.

2) Pelaksanaan tindakan (action)

a) Guru pembimbing peneliti memberikan informasi kepada siswa tentang penyelenggaraan bimbingan kelompok.

b) Guru pembimbing peneliti menetapkan siswa-siswa yang menjadi anggota bimbingan kelompok.

c) Guru pembimbing peneliti melaksanakan layanan bimbingan kelompok.

d) Guru pembimbing peneliti bersama anggota kelompok membahas topik masalah.

3) Pengamatan (observation)

Pengamatan/observasi dilaksanakan oleh guru pembimbing peneliti dan kolaborator. Adapun pelaksanaannya meliputi:

a) Kolaborator mengamati pelaksanaan bimbingan kelompok yang dilakukan oleh guru pembimbing peneliti.

b) Guru pembimbing peneliti dan kolaborator mengamati siswa selama mereka mengikuti layanan bimbingan kelompok.

c) Guru pembimbing peneliti dan kolaborator mengamati keaktifan anggota bimbingan kelompok, dan dinamika kelompok.

4) Refleksi (reflection)

Hasil observasi yang dilakukan guru pembimbing peneliti bersama kolaborator dianalisis oleh Guru Pembimbing dan kolaborator dengan cara berdiskusi, serta berkoordinasi agar hasil yang diperoleh tidak bersifat subjektif.

Hasil diskusi dengan kolaborator digunakan untuk mengetahui apa yang dapat dilaksanakan dan dicapai dalam pelaksanaan tindakan layanan bimbingan kelompok, sekaligus merupakan cara untuk mengetahui kekurangan dan ketidakberhasilan tindakan bimbingan kelompok yang telah dilaksanakan. Kekurangan pada tindakan layanan bimbingan kelompok sebelumnya, yakni pada siklus I, dapat direncanakan pembaharuan tindakan yang akan dilaksanakan pada siklus II.

Siklus II

1) Perencanaan (Planning)

Kegiatan yang dilakukan yaitu:

a) Membuat rencana tindakan layanan bimbingan kelompok yang telah diperbaiki berdasarkan kekurangannya yang diketahui melalui pelaksanaan siklus I.

b) Membuat pedoman observasi untuk melihat aktivitas guru pembimbing dalam melaksanakan bimbingan kelompok.

c) Membuat pedoman observasi untuk siswa saat mengikuti kegiatan bimbingan kelompok dengan memasukkan alumni sukses pendidikan.

d) Membuat pedoman observasi untuk mengamati situasi dan kondisi pada saat kegiatan layanan bimbingan kelompok berlangsung.

2) Pelaksanaan tindakan (action)

a) Guru pembimbing peneliti memberikan informasi hasil capaian tentang penyelenggaraan bimbingan kelompok kepada siswa anggota kelompok.

b) Guru pembimbing peneliti mengajukan topik permasalahan dengan disertai alasan yang menggugah dan perlu dibahas dalam kelompok.

c) Guru pembimbing peneliti melaksanakan layanan bimbingan kelompok dengan modeling alumni sukses pendidikan.

3) Pengamatan (observation)

a) Kolaborator mengamati pelaksanaan bimbingan kelompok yang dilakukan oleh guru pembimbing peneliti.

b) Guru pembimbing peneliti dan kolaborator mengamati siswa, selama 
mereka mengikuti layanan bimbingan kelompok.

\section{4) Refleksi (reflection)}

Hasil observasi diperoleh dari pengamatan pada siklus ke 2 yang dilakukan oleh guru pembimbing peneliti bersama kolaborator, kemudian dianalisis oleh guru pembimbing peneliti dan kolaborator dengan cara berdiskusi dan berkoordinasi agar hasil yang diperoleh objektif. Berdasarkan hasil refleksi siklus ke 2, akan diketahui bahwa kegiatan yang dilakukan sudah sesuai dengan hipotesis yang diharapkan yaitu terjadinya peningkatan perencanaan studi lanjut.

\section{HASIL DAN PEMBAHASAN}

\section{Deskripsi Kondisi Awal}

Hasil penelitian menunjukkan bahwa perencanaan studi lanjut di kelas XII IPA3 SMA Negeri 2 Pati semester genap tahun 2018/2019 masih rendah. Hal ini dibuktikan dengan masih ditemukannya siswa-siswa yang mempunyai masalah sosial dalam perencanaan studi lanjut.

Hasil analisis data kuesioner perencanaan studi lanjut pada kondisi awal/pra siklus kepada 39 siswa kelas XII IPA3 adalah sebagai berikut: siswa yang melanjutkan untuk bekerja setelah lulus 2 siswa $(5,12 \%)$, siswa yang memilih ke perguruan tinggi setelah lulus 23 siswa (58,97\%), siswa memilih perguruan tinggi namun memiliki problem sosial sebanyak 10 siswa $(25,64 \%)$, siswa yang memilih mengikuti kursus setelah lulus sebanyak 4 siswa $(10,25 \%)$.

\section{Tindakan Layanan Bimbingan Konseling Kelompok}

Kriteria penilaian pada tindakan layanan Bimbingan Kelompok (BKp) dikelompokkan menjadi 5 tingkatan kualitas, yaitu:

a) Kurang sekali $: \geq 20$

b) Kurang :21-45

c) Sedang : $46-70$

d) Baik : :71-95

e) Amat Baik : $96-120$

Perencanaan layanan bimbingan kelompok dilaksanakan kepada 10 siswa yang berencana melanjutkan ke perguruan tinggi namun masih memiliki problem sosial. Layanan Bimbingan Kelompok (BKp) pada siklus I dan siklus II diperoleh data sebagaimana yang tersaji dalam Tabel 1.

Tabel 1 menunjukkan bahwa pada siklus I terdapat peningkatan skor pada semua tahap Bimbingan Konseling Kelompok (BKp) dari tahap pembentukan, peralihan, kegiatan, dan pengakhiran pada BKp 1 terhadap BKp II. Skor rata-rata layanan adalah 56 , termasuk dalam kategori sedang.

Siklus II terdapat peningkatan skor pada semua tahap Bimbingan Konseling Kelompok (BKp) dari tahap pembentukan, peralihan, kegiatan, dan pengakhiran pada BKp 1 terhadap BKp II. Skor rata-rata layanan adalah 77,25 dan termasuk dalam kategori baik. Hal ini dapat disimpulkan bahwa terdapat peningkatan layanan bimbingan konseling dari kategori sedang pada siklus I menjadi kategori baik pada siklus II.

Tabel 1.

Perbandingan Hasil Skor Tindakan Layanan BKp Siklus I dan Siklus II

\begin{tabular}{lcccc}
\hline Tahap BKp & \multicolumn{2}{c}{ Siklus I } & \multicolumn{2}{c}{ Siklus II } \\
\cline { 2 - 5 } & BKp I & BKp II & BKp I & BKp II \\
\hline Pembentukan & 52 & 60 & 76 & 96 \\
Peralihan & 40 & 56 & 64 & 80 \\
Kegiatan & 54 & 56 & 66 & 76 \\
Pengakhiran & 55 & 75 & 70 & 90 \\
Jumlah & 201 & 247 & 276 & 342 \\
Skor rata-rata & \multicolumn{2}{c}{$224: 4=56$} & $309: 4=77,25$ \\
& \multicolumn{3}{c}{ (Kategori sedang) } & (Kategori Baik) \\
\hline
\end{tabular}


Tabel 2.

Perbandingan Skor Kondisi Siswa dalam Pelayanan BKp Siklus 1 dan Siklus 2

\begin{tabular}{clcccccccc}
\hline No & \multirow{2}{*}{ Subjek } & \multicolumn{2}{c}{ Siklus I } & Rata- & Kategori & \multicolumn{2}{c}{ Siklus II } & Rata- & Kategori \\
& & BKp I & BKp II nnata & rata & & BKp I & BKp II & & \\
\hline 1 & AC & 32,75 & 34,25 & 33,50 & Kurang & 50,75 & 65 & 57,87 & Sedang \\
2 & BR & 61 & 62,25 & 57,87 & Sedang & 65,75 & 81,50 & 73,62 & Baik \\
3 & DJ & 51,50 & 61 & 56,25 & Sedang & 55,25 & 69,50 & 62,37 & Sedang \\
4 & DNS & 41,25 & 45,50 & 43,37 & Kurang & 49,50 & 63,50 & 56,50 & Sedang \\
5 & IKN & 29,25 & 45 & 37,12 & Kurang & 52,50 & 61,25 & 56,87 & Sedang \\
6 & MRS & 33,75 & 41 & 37,37 & Kurang & 49,50 & 66 & 57,75 & Sedang \\
7 & NSY & 45 & 57,5 & 51,25 & Sedang & 62,75 & 67,50 & 65,12 & Sedang \\
8 & SW & 23,25 & 40 & 31,62 & Kurang & 57,50 & 55 & 56,25 & Sedang \\
9 & WRI & 33,75 & 39,25 & 36,50 & Kurang & 53,25 & 56,25 & 54,75 & Sedang \\
10 & SHI & 43,75 & 46,50 & 45,12 & Kurang & 57,75 & 62,25 & 60 & Sedang \\
\hline
\end{tabular}

Kondisi Siswa dalam Pelayanan Bimbingan Konseling Kelompok

Pengamatan terhadap siswa pada saat mengikuti BKp Siklus 1 secara lengkap tersaji dalam Tabel 2. Hasil penelitian menunjukkan bahwa terdapat peningkatan skor dari semua kondisi subjek pada BKp 1 terhadap BKp II. Meskipun demikian, berdasarkan rerata skor dapat dilihat bahwa 6 subjek berada dalam kategori kurang dan 4 subjek dalam kategori sedang.

Siklus II, seluruh subjek mengalami peningkatan skor dari BKp I terhadap BKp II. Berdasarkan rerata skor, sebagian besar (90\%) Subjek berada dalam kondisi sedang, dan 10\% yang berada dalam kondisi baik. Dengan kata lain, kategori Subjek dengan kondisi kurang sudah tidak ada lagi pada siklus II.

\section{Situasi Pelaksanaan Bimbingan Konseling Kelompok}

Pengamatan terhadap situasi dan kondisi saat pelaksanaan BKp siklus I dan siklus II dijelaskan pada Tabel 3. Terdapat perubahan positif dari setiap tahapan pelaksanaan kegiatan BKp I ke BKp II baik pada siklus I maupun siklus II. Hasil pengamatan pada tahap pembentukan menunjukkan bahwa situasi pada BKp I terjadi perubahan dari situasi tegang menjadi lebih santai setelah mendapatkan penjelasan dari Guru BK. Perubahan situasi juga terjadi pada tahap peralihan, dari semula situasi siswa yang masih bingung pada BKp I menjadi situasi yang menyenangkan pada BKp II. Begitu juga pada tahap kegiatan, anggota terlihat kurang memahami permasalahan pada BKp I menjadi lebih mudah memahami permasalahan dengan bantuan model pada BKp II. Pada tahap pengakhiran pun demikian, sebagian anggota BKp I menunjukkan wajah senang ketika kegiatan berakhir pada BKp I berubah menjadi enggan untuk mengkahiri kegiatan pada BKp II.

Siklus II menunjukkan adanya perubahan positif dari setiap tahapan pelaksanaan kegiatan BKp I ke BKp II. Tahap pembentukan menunjukkan situasi pada BKp I terjadi perubahan dari situasi yang menyenangkan menjadi situasi bersungguh-sungguh dalam merespon stimulus. Perubahan situasi juga terjadi pada tahap peralihan, dari situasi siswa yang menunjukkan pertanyaan terkait dengan tugas dan tanggung jawab pada BKp I menjadi situasi lebih berani mengemukakan pendapat pada BKp II.

Pada tahap kegiatan, pembahasan permasalahan lebih mendalam pada BKp I menjadi lebih tercerahkan dengan solusi permasalahan pada BKp II. Tahap pengakhiran pun demikian, sebagian anggota menunjukkan kesan yang baik pada BKp I meningkat. Hal ini ditandai dengan munculnya usulan untuk mengadakan kegiatan bimbingan konseling kelompok terkait permasalahan pribadi pada BKp II. 
Tabel 3.

Perbandingan Situasi Pelaksanaan Layanan BKp Siklus 1 dan Siklus II

\begin{tabular}{|c|c|c|c|c|}
\hline \multirow{2}{*}{$\begin{array}{c}\text { Tahapan } \\
\text { Kegiatan BKp }\end{array}$} & \multicolumn{2}{|c|}{ Siklus I } & \multicolumn{2}{|c|}{ Siklus II } \\
\hline & ВKр I & BKp II & BKp I & BKp II \\
\hline Pembentukan & $\begin{array}{l}\text { Situasi terasa agak } \\
\text { tegang pada saat } \\
\text { guru pembimbing } \\
\text { menjelaskan } \\
\text { tentang asas-asas } \\
\text { kegiatan. }\end{array}$ & \begin{tabular}{lr}
\multicolumn{2}{l}{ Siswa sudah mulai } \\
mengerti & dengan \\
penjelasan & guru \\
BK, rehingga \\
suasana & lebih \\
santai. &
\end{tabular} & $\begin{array}{lr}\text { Situasi yang } & \text { semula } \\
\text { agak kaku, berubah } & \\
\text { menjadi menyenangkan } & \text { guru } \\
\text { setelah } & \\
\text { pembimbing } & \\
\text { menunjukkan } & \text { empati } \\
\text { pada saat anggota } \\
\text { mengungkapkan diri. } \\
\text { Permainan } & \text { baru } \\
\text { menjadikan } & \text { suasana } \\
\text { kelompok } & \text { semakin } \\
\text { hangat. } & \end{array}$ & $\begin{array}{lr}\text { Empati } & \text { yang } \\
\text { ditunjukkan } & \text { guru } \\
\text { pembimbing } & \text { ditambah } \\
\text { pernyataan } & \text { kesediaan } \\
\text { membantu } & \text { secara } \\
\text { khusus, } & \text { menjadikan } \\
\text { anggota } & \text { kelompok } \\
\text { bersungguh-sungguh } \\
\text { dalam } & \text { merespon } \\
\text { stimulasi yang diterima. }\end{array}$ \\
\hline Peralihan & $\begin{array}{lr}\text { Siswa } & \text { masih } \\
\text { bingung } & \text { dengan } \\
\text { kegiatan } & \text { yang } \\
\text { diadakan. } & \end{array}$ & $\begin{array}{l}\text { Situasi tidak } \\
\text { tegang dan lebih } \\
\text { menyenangkan } \\
\text { setelah anggota } \\
\text { mengetahui } \\
\text { kegiatan yang } \\
\text { akan dijalani. }\end{array}$ & $\begin{array}{lr}\text { Kesiapan } & \text { anggota } \\
\text { terlihat } & \text { dari } \\
\text { pertanyaan, } & \text { terkait } \\
\text { tugas dan tanggung } \\
\text { jawab pada kegiatan } \\
\text { yang akan dijalani. }\end{array}$ & $\begin{array}{l}\text { Pemberian contoh dari } \\
\text { guru pembimbing } \\
\text { mendorong anggota } \\
\text { kelompok } \quad \text { untuk } \\
\text { mengemukakan } \\
\text { pendapatnya. }\end{array}$ \\
\hline Kegiatan & $\begin{array}{lr}\text { Anggota } & \text { BKp } \\
\text { terlihat } & \text { kurang } \\
\text { paham } & \text { secara } \\
\text { utuh } & \text { tentang } \\
\text { masalah } & \text { yang } \\
\text { diajukan } & \text { guru } \\
\text { pembimbing. }\end{array}$ & $\begin{array}{lr}\text { Masalah } & \text { yang } \\
\text { diajukan } & \text { lebih } \\
\text { cepat dipahami } & \text { detelah anggota } \\
\text { bereksplorasi } \\
\text { dengan bantuan } \\
\text { model. }\end{array}$ & $\begin{array}{lr}\text { Pembahasan } & \text { masalah } \\
\text { semakin } & \text { mendalam } \\
\text { dengan diperolehnya } & \\
\text { kesempatan } & \text { setiap } \\
\text { anggota } & \text { untuk } \\
\text { berbicara. } & \end{array}$ & $\begin{array}{l}\text { Berbagi pengalaman } \\
\text { bersama alumni sukses } \\
\text { pendidikan dalam } \\
\text { menghadapi masalah } \\
\text { antaranggota kelompok } \\
\text { menjadikan anggota } \\
\text { kelompok memiliki } \\
\text { gambaran solusi dari } \\
\text { permasalahan yang } \\
\text { sedang dihadapi. }\end{array}$ \\
\hline Pengakhiran & $\begin{array}{l}\text { Sebagian anggota } \\
\text { BKp menunjukkan } \\
\text { raut wajah ceria } \\
\text { dengan } \\
\text { berakhirnya } \\
\text { kegiatan. }\end{array}$ & $\begin{array}{lr}\text { Ada keengganan } \\
\text { untuk mengakhiri } \\
\text { kegiatan } & \text { karena } \\
\text { masalah } & \text { belum } \\
\text { tuntas. } & \end{array}$ & $\begin{array}{lr}\text { Anggota } & \text { BKp } \\
\text { menunjukkan } & \text { kesan } \\
\text { yang baik } & \text { terhadap } \\
\text { pelaksanaan } & \text { layanan } \\
\text { bimbingan } & \text { kelompok } \\
\text { yang diikuti } & \end{array}$ & $\begin{array}{l}\text { Adanya usulan untuk } \\
\text { melaksanakan kegiatan } \\
\text { bimbingan kelompok } \\
\text { lagi, dengan membahas } \\
\text { topik yang berkenaan } \\
\text { dengan masalah } \\
\text { pribadi. }\end{array}$ \\
\hline
\end{tabular}

\section{Hasil Akhir Penelitian Tindakan Kelas}

Hasil pelaksanaan bimbingan kelompok (BKp) pada siklus I yang dilaksanakan tanggal 11 sampai 14 Februari 2019, terdapat 5 orang siswa yang memilih ke perguruan tinggi dan memiliki problem sosial, 29 orang siswa melanjutkan ke perguruan tinggi, 4 orang siswa yang memilih mengikuti kursus setelah lulus, 1 orang siswa yang melanjutkan untuk bekerja setelah lulus. Kesimpulan yang didapat dari pelaksanaan bimbingan kelompok pada siklus I adalah terjadi penurunan 5 orang siswa memiliki problem sosial dalam memilih ke perguruan tinggi, dan terjadi peningkatan pada jumlah siswa yang memilih melanjutkan ke perguruan tinggi sebesar 29 orang siswa. Dengan kata lain layanan bimbingan kelompok mencapai keberhasilan 50\%.

Penelitian ini menunjukkan hasil yang positif sebagaimana ditunjukkan Tabel 4 . Terdapat kesesuaian antara problem siswa dengan pengalaman modeling alumni sukses pendidikan dan kekhasan pelaksanaan BKp. Perencanaan studi lanjut dapat ditingkatkan 
Tabel 4.

Hasil Akhir PTBK

\begin{tabular}{|c|c|c|}
\hline Tindakan Guru Pembimbing & Dampak Tindakan & Hasil \\
\hline $\begin{array}{l}\text { Layanan BKp Siklus I = Sedang } \\
\text { Rata-rata }(56,75)\end{array}$ & $\begin{array}{l}\text { Kondisi siswa= } 4 \text { siswa } \\
\text { "sedang" tetapi dalam posisi } \\
\text { atas, dan } 6 \text { siswa "kurang" } \\
\text { dalam posisi tengah. } \\
\text { Iklim penyelenggaraan= } \\
\text { sedang }\end{array}$ & $\begin{array}{l}\text { Peningkatan perencanaan studi } \\
\text { lanjut. } \\
\text { Semua perencanaan siswa setelah } \\
\text { lulus SMA dari } 39 \text { siswa sebagai } \\
\text { sampel menjadi } 10 \text { siswa yang } \\
\text { memiliki problem sosial. }\end{array}$ \\
\hline $\begin{array}{l}\text { Layanan BKp siklus II= Baik } \\
\text { Rata-rata }(77,125)\end{array}$ & $\begin{array}{l}\text { Kondisi siswa }=10 \text { siswa } \\
\text { "sedang" tetapi dalam posisi } \\
\text { atas. } \\
\text { Iklim penyelenggaraan= Baik }\end{array}$ & $\begin{array}{l}\text { Peningkatan perencanaan studi } \\
\text { lanjut setelah lulus SMA dari } 39 \\
\text { siswa menjadi 0 siswa yang } \\
\text { memiliki problem sosial. }\end{array}$ \\
\hline
\end{tabular}

melalui penerapan layanan Bimbingan Kelompok (BKp) dengan menggunakan modeling alumni sukses pendidikan.

Siklus II menunjukkan bahwa terjadi peningkatan perencanaan studi lanjut setelah lulus SMA dari 10 siswa menjadi 0 siswa yang memiliki masalah sosial. Pelaksanaan Bimbingan Kelompok (BKp) berlangsung dengan semangat yang tinggi, kerjasama yang lancar dan mantap, saling mempercayai diantara anggota-anggotanya, dan kerelaan dari modeling alumni sukses pendidikan. Masingmasing anggota bersikap sebagai kawan dalam arti yang sebenarnya, mengerti dan menerima secara positif tujuan bersama dalam kelompok. Anggota kelompok saling memotivasi sehingga terbentuk kesadaran akan penyelenggaraan BKp yang dilaksanakan, dan dengan kesadaran mereka berusaha untuk merubah sikap menuju ke arah positif.

\section{KESIMPULAN DAN SARAN}

\section{Kesimpulan}

Kesimpulan penelitian adalah layanan bimbingan kelompok dapat meningkatkan perencanaan studi lanjut agar siswa lebih tertata dalam pemilihan studi lanjutnya.

\section{Saran}

Guru adalah faktor sentral keberhasilan siswa. Guru hendaknya lebih memperhatikan siswa-siswanya terutama membantu siswa yang memiliki permasalahan sosial dalam proses pengambilan keputusan dan perencanaan yang lebih terarah terutama perencanaan studi lanjut setelah lulus dari SMA.

Sekolah berpengaruh dalam peningkatan perencanaan studi lanjut siswa. Sekolah harus lebih meningkatkan lagi pelayanannya dalam mempersiapkan siswa menuju ke jenjang karir maupun pendidikan selanjutnya. Sekolah perlu membentuk tim untuk mulai mengidentifikasi bakat siswa dari awal. Diharapkan pembentukan jati diri dan pengarahan siswa setelah lulus lebih mudah dan lebih tepat.

\section{DAFTAR PUSTAKA}

Aliem, N., Sugiharto, D. Y. P., \& Awalya. (2017). Group Counseling with Cognitive Restructuring Technique to Improve The Self-Efficacy and Assertiveness of Students Who Experienced Advanced Study Anxiety. Jurnal Bimbingan Konseling UNNES, 6(1), 106-117.

Aprilia, R., Madihah., \& Susanto, D. (2017). Meningkatkan Kemampuan Komunikasi Interpersonal Siswa melalui Layanan Bimbingan Kelompok dengan Teknik Assertive Training. An Nur: Jurnal Mahasiswa Bimbingan dan Konseling, 3(3), 45-58.

Alwisol. (2009). Psikologi Kepribadian. Malang: UMM Press.

Iwanramadanie. (2011) Manajemen Penilaian Dan Study Lanjut. Forum Belajar Kita (counseling). Diakses tanggal 10 Agustus 2019. http://iwanramadanie. 
blogspot.com/2011/12/manajemenpenilaian-dan-study-lanjut.html).

Korohama, K. E. P., Wibowo, M. E., \& Tadjri, I. (2017). Model Bimbingan Kelompok dengan Teknik Modeling untuk Meningkatkan Kematangan Karir Siswa. Jurnal Bimbingan Konseling UNNES, 6 (1), 68-76.

Luddin, A. B. M. (2010). Dasar-Dasar Konseling: Tinjauan Teori dan Praktik. Bandung: Citapustaka Media Perintis.

Masraroh \& Latifatul. (2012). Efektifitas Bimbingan Kelompok Teknik Modelling untuk Meningkatkan Self Efficacy Akademik Siswa (Studi Eksperimen Kuasi di Kelas X Sekolah Atas Laboratorium Universitas Pendidikan Indonesia). Jurnal Universitas Pendidikan Indonesia, 28(2), 146-158.

Munadi, I. (2010). New Born Super Muslim Strategi Terdasyat menjadi Kaya-SuksesBahagia Mati, Insya Allah Masuk Surga. Jakarta: PT Elex Media Komputindo.

Nafisah, H. (2016). Motivasi Siswa Terhadap Studi Lanjut (Studi di SMA N Jatilawang) (Skripsi). Purwokerto: Institut Agama Islam Negeri.

Prayitno. (2012). Jenis Layanan dan Kegiatan Pendukung Konseling. Padang: FIP Universitas Negeri Padang.

Sulistyowati, A. N. L. (2015). Layanan Bimbingan Kelompok untuk Meningkatkan Keterampilan Belajar Siswa. EDUKASIA: Jurnal Penelitian Pendidikan Islam STAIN Kudus, 10(2), 85-100.
Suryani, C. D. (2018). Peningkatan Kepercayaan Diri melalui Layanan Bimbingan Kelompok pada Siswa Kelas X IPS 2 SMK Negeri 1 Bandung. Jurnal Penelitian Pendidikan LPPM Universitas Pendidikan Indonesia, 18(3), 84-95.

Sulistyowati, D. D., Nasir, M. (2009) Psikologi Pendidikan dan Bimbingan, Jurnal $P P B$ UNESA, 10 (1), 90-100.

Syamsudin, A. (2012). Psikologi Kependidikan Perangkat Sistem Pengajaran: Modul. Bandung: Rosdyakarya, 2012.

Tohirin. (2011). Bimbingan dan Konseling di Sekolah dan Madrasah (Berbasis Integrasi). Jakarta: PT Raja Grafindo Persada.

UU Nomor 20 Tahun 2003 tentang Sistem Pendidikan Nasional.

Ward \& Peppard (2012). Strategic Panning for Information System. Jakarta: Elex Media Komputindo.

Wuryanano. (2009). Super Mind for Successful Life. Jakarta: Elex Media Komputindo.

Yulihastuti, N. H. (2018). Penerapan Teknik Modeling untuk meningkatkan Sikap Wirausaha pada Siswa. Jurnal Litbang: Media Informasi Penelitian, Pengembangan dan IPTEK, 14(2), 139146.

\section{BIODATA PENULIS}

Nur khixmah Yulihastuti, S.Pd, M.Pd, lahir di Pati 19 Juli 1975, Menempuh pendidikan S1 Bimbingan Konseling dan S2 Pendidikan Ekonomi di Universitas Sebelas Maret Surakarta. Saat ini bekerja sebagai guru Bimbingan Konseling di SMA Negeri 2 Pati 
